\title{
The Impact of Labour Migration on Human Capital: The Case of Tajikistan
}

The Impact of Labour Migration on Human Capital: The Case of Tajikistan

Repercusiones de las migraciones de trabajo sobre el capital humano: el caso de

Tayikistán

Saodat Olimova

\section{(2) OpenEdition}

Journals

Electronic version

URL: https://journals.openedition.org/remi/5239

DOI: $10.4000 /$ remi.5239

ISSN: $1777-5418$

Publisher

Université de Poitiers

Printed version

Date of publication: 1 December 2010

Number of pages: 181-197

ISBN: 978-2-911627-56-9

ISSN: 0765-0752

\section{Electronic reference}

Saodat Olimova, "The Impact of Labour Migration on Human Capital: The Case of Tajikistan", Revue européenne des migrations internationales [Online], vol. 26 - n³ | 2010, Online since 01 December 2013, connection on 15 April 2022. URL: http://journals.openedition.org/remi/5239 ; DOI: https://doi.org/ 10.4000/remi.5239 


\title{
Note de recherche
}

\section{The Impact of Labour Migration on Human Capital: The Case of Tajikistan}

\author{
Saodat OLIMOVA ${ }^{1}$
}

\section{INTRODUCTION}

The UN High-level Dialogue on International Migration and Development in September 2006 and the Global Forums on Migration and Development have admitted the connection between migration and development. Effective management of labour migration requires the adjustment of migration for the goals of the overall economic development and re-alignment of migration flows with capital flows, technology transfers and policies for expansion of human capital, encouragement of entrepreneurship, and retention of skilled human resources.

Moreover, as some countries demonstrate the variety of patterns of migration management and distinct economic and socio-cultural factors make the positive impact of labour migration on economic development highly questionable. To understand the connection between labour migration and economic development it is necessary to look at the impact of labour migration on various aspects of economic development in different countries. For this reason the focus of this article is made on the impact of labour migration on human capital in Tajikistan.

Tajikistan is chosen to serve as a case study of the impact of labour migration for several reasons. First of all, being a part of the Soviet Union, Tajikistan has been experiencing structural changes in the process of transition from the Soviet economy. Therefore, the impact of labour migration on economic development is particularly important, since we have an opportunity to witness the interaction of migration and other indicators of economic development in the context of the general process of economic transformation. Secondly, Tajikistan is one the countries which has been experiencing an extremely high level of labour migration over the past decade.

1 Research Center SHARQ (ORIENS), 7 Bofanda Street, Ap. 9, Dushanbe, Tajikistan, plo 734042, TellFax: +(992-37) 22189 95; sharq@tajik.net, s_olimova@mail.ru 
Tajikistan, along with other Central Asian republics, underwent deep modernization in the Soviet period. One of the outcomes of this modernization was the high level of human capital in Tajikistan. Most of the works on economic development agree on the notion that the high level of human capital (and education) is one of the determinants of economic development. Given this fact, it is interesting to see the connection between the development of human capital in the post-Soviet Tajikistan and labour migration. The main questions to be answered are what are the dynamics of human capital development in the process of economic transformation in Tajikistan and what is the impact of labour migration on the development of human capital.

In this work we define human capital as a set of skills and competences possessed by the labour force and which have a direct positive effect on the level of economic development. In this context we made a particular emphasis on the analysis of formal educational levels, on-the-job training, and other sources of acquisition of professional skills. Other determinants of human capital such as health care, nutritional levels, life expectancy have been omitted from this study, since these determinants of human capital do not have a direct positive effect on economic development.

\section{METHODOLOGY}

The lack of clear understanding of the impact of labour migration on education primarily stems from methodological issues. Most of the empirical quantitative studies of labour migration are based on household surveys. However, this type of data is not a good source of the analysis of dynamics of determinant of human capital and as such cannot explain the evolution of the variables in question over time.

At the same time, the qualitative methods, which are used mostly in anthropological studies, give enough information to analyze a phenomenon in depth, but cannot serve as a ground for analysis of aggregate behavior of labour migrants or migrant households. Therefore, the mixed methodology used in this study is the most relevant because it allows us to employ an interdisciplinary approach to study the problem.

We employ data from a variety of sources, including official statistics, data from the Living Standards Measurement Survey of 2007 (TLSS, 2007), the Labour Force Survey (SCSRT, 2006), data from the European Training Foundation (ETF) Labour Market Analysis in Tajikistan (Quddusov, 2009), UNDP Informal Economy Survey (Olimov, 2007). We also use data collected by the author of this study in the following research projects: Asian Development Bank (ADB) Labour Migration and Poverty Survey (Brown, Olimova and Boboev, 2008), the Human Capital Development Study in Tajikistan conducted by the European Training Institute and SHARQ Research Center in 2009. In addition, we employ results of face-to-face interviews with migrants and employers in November 2008, Tajikistan.

There are a number of studies in different countries, which focus on the impact of migration on the human capital. Most of these studies conclude that migration has a positive impact on the human capital by lowering the extreme poverty levels and expanding the income 
level through remittances from migrants abroad. At the same time, a number of studies show that the positive impact of labour migration on income growth may not have a simultaneous positive effect on the level of human capital (see, for example, De Haan, 2005).

Usually, it is hypothesized that labour migration has a positive impact on human capital, because money remittances from labour migrants are spent on education of their household members, which raises the overall level of education in a country. McKenzie and Rapoport (2006) find that labour migration affects the level of education through three different channels: 1) direct income effect through money remittances, 2) direct substitution effect on demand for child labour (labour migration lowers supply of adult employees and therefore increases demand for child labour), and 3) indirect effect on the expected earnings (if expected wage in destination country exceeds wages in source country, the cost of staying at school for one extra year (in terms of foregone wage) in source country is high, and potential labour migrants have stronger incentives to leave schooling in return for an earlier opportunity to find employment in the destination country). While migration has positive impact on human capital through the first channel, the impact of migration on human capital through the second and third channels is negative. In addition, labour migration may have negative impact on education through higher absenteeism of school children, whose parents are abroad and cannot control school attendance.

Nevertheless, a number of empirical studies show that money remittances have positive impact on education in migrant household as opposed to household without migrants (see Cox Edwards and Ureta, 2003; Hanson and Woodruff, 2003).

In particular, Cox Edwards and Ureta (2003) find that monetary remittances are positively correlated with school attendance and negatively correlated with school dropout rates. Conversely, McKenzie and Rapoport (2006) find that migration is negatively correlated with school attendance rates and overall education level. These authors find that the negative impact of migration on education due to higher demand for child labour overweighs the positive impact of migration due to money remittances and higher income levels. This study along with others show that aside from purely economic factors the impact of migration on education and human capital depend on a variety of social and cultural factors, including household structure (Hanson and Woodruff, 2003; Acosta, 2006). For instance, some studies show children in remittance receiving households have more opportunities to attend private schools and obtain professional education. Additional income from remittances can cover expenses on private education and help keep children from entering labour market early (Hanson and Woodruff, 2003; Thieme, 2009).

Thus, we can summarize the findings of other studies in the following manner. On the one hand, we find that children from remittance receiving household have easier access to education, since remittances can be spent on school supplies, books, and other education-related items. In addition, some migrants use their earnings to finance attendance of their children in universities. On the other hand, due to absence of family members, migration leads to higher school absenteeism, lower academic success, and higher dropout rates of children in migrant households. This leads to the worsening of the quality of acquisition of education and lowers the educational level overall. 
In the context of this summary it is interesting to look at the specifics of educational system of Tajikistan. In the Soviet era Tajikistan enjoyed high levels of equity in access to education and the virtually universal coverage of the education system. In the transition period since 1991, the education attainment levels and literacy levels in Tajikistan remained relatively high, even despite the civil conflict and the general impoverishment of population. Nevertheless, some negative tendencies in the dynamics of human capital development manifested themselves in this period.

Table 1: Main Demographic Indicators in Tajikistan

\begin{tabular}{|l|c|}
\hline Total population (Millions) & $7.28(2008)$ \\
\hline Annual growth rate of population (\%) & $2.0(2006-2008)$ \\
\hline Literacy level among adults (\%) & $99.6(2007)$ \\
\hline Share of population residing in urban areas & $26.4(2007)$ \\
\hline Share of population subsisting on less than USD 1.25 a day (\%) & $21.5(2004)$ \\
\hline
\end{tabular}

Source: State Statistical Committee of Tajikistan, www.stat.tj/english/database.htm

The general trends in the post-Soviet people resulted in the lower level of education of young people in comparison to their parents, significant drop in the quality of education and a higher inequity in access to education for certain social groups.

Table 2: Demographic Indicators by Level of Schooling

\begin{tabular}{|c|c|c|c|c|c|c|}
\hline & 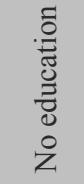 & 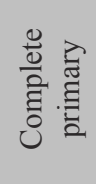 & $\frac{\frac{0}{0}}{\tilde{\Xi}} \cdot \frac{0}{\tilde{0}}$ & 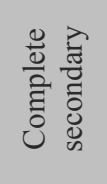 & 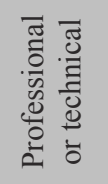 &  \\
\hline $\begin{array}{l}\text { Share of population aged } \\
\text { above } 15 \text { in } 1989\end{array}$ & $0.0 \%$ & $0.0 \%$ & $25.2 \%$ & $52.1 \%$ & $13.1 \%$ & $10.6 \%$ \\
\hline Men only & $0.0 \%$ & $0.0 \%$ & $20.1 \%$ & $50.9 \%$ & $13.6 \%$ & $10.3 \%$ \\
\hline Women only & $0.0 \%$ & $0.0 \%$ & $22.1 \%$ & $53.6 \%$ & $8.5 \%$ & $6.6 \%$ \\
\hline $\begin{array}{l}\text { Share of population aged } \\
\text { above } 15 \text { in } 2000\end{array}$ & $0.0 \%$ & $5.9 \%$ & $19.1 \%$ & $57.5 \%$ & $6.6 \%$ & $8.9 \%$ \\
\hline Men only & $0.0 \%$ & $5.0 \%$ & $17.0 \%$ & $59.0 \%$ & $8.0 \%$ & $11.0 \%$ \\
\hline Women only & $0.0 \%$ & $7.0 \%$ & $22.0 \%$ & $60.0 \%$ & $6.0 \%$ & $5.0 \%$ \\
\hline $\begin{array}{l}\text { Share of population aged } \\
\text { above } 15 \text { in } 2007\end{array}$ & $0.7 \%$ & $8.7 \%$ & $22.1 \%$ & $48.1 \%$ & $11.0 \%$ & $8.8 \%$ \\
\hline Men only & $0.5 \%$ & $7.1 \%$ & $17.7 \%$ & $45.9 \%$ & $15.7 \%$ & $13.2 \%$ \\
\hline Women only & $0.9 \%$ & $10.1 \%$ & $26.1 \%$ & $51.4 \%$ & $6.7 \%$ & $4.8 \%$ \\
\hline
\end{tabular}

Source: TLSS, 2007 
Table 2 presents the level of education of individual of ages 15 and above according to official data sources (census data of 1989 and 2000 and Tajik Living Standards Survey (TLSS, 2007). Although the share of individuals without education in the census of 1989 and 2000 was 0 percent, it raised to $0.7 \%$ in 2007 according to the TLSS 2007 data.

Despite the small number of people with no education $(0.7 \%)$, there is an increasing trend in the number of those with no education across different age groups. Conversely, the share of people with higher education and professional education fell down in $1989-2007$ by $1.8 \%$ and $2.1 \%$ respectively. The biggest changes are observed in the educational attainment levels of women: the share of women with university and professional education dropped. We can also observe that as opposed to the Soviet period in 2007 the share of women of ages 15 and above with only primary education rose to $10.1 \%$.

When studying the issue of human capital development, it is necessary to address the labour force participation rates. According to the data from the Tajik Living Standards Survey (TLSS, 2007), 43.8\% of the total population was economically active in 2007 , with $58.1 \%$ of men economically active to $31.1 \%$ of women. The analysis of educational attainment shows that $0.35 \%$ of the economically active population have no education at all, while $2.97 \%$ have only primary education. Meanwhile, $15.1 \%$ of the labour force has incomplete secondary education and $49.59 \%$ have complete secondary education, while only $16.44 \%$ have technical or professional education and $14.64 \%$ have higher education. More than $68 \%$ of those with technical or professional and higher education are economically active against $45 \%$ of those with only secondary education. Thus, the acquisition of technical or professional education is associated with an increase in participation by $23 \%{ }^{2}$

These figures demonstrate that while the general quality of the labour force is relatively high (as shown by the small number of people with no education or only basic schooling) only a third all members of the labour force have professional training or higher. Meanwhile, the participation rate for individuals with professional training or higher education is significantly higher than for those with only secondary education.

Moreover, there is a discrepancy between the number of years of schooling and the poor range of skills acquired. Although students attend school for many years, their skills and knowledge fall far below expected levels of the state standard of education.

The falling quality of education is especially noticeable for groups such as rural residents, the poorer sectors and girls. The variable quality of education leads to rising inequity in access to education as poor input at the basic level can bar entry to higher level tuition. Women and rural residents, who find it hard to access schooling and receive low quality education, also have a weaker rate of participation in the labour market.

What are the reasons which led to the deterioration of human capital in Tajikistan? To answer this question we first need to characterize the labour market in Tajikistan in the first decade after 1991.

2 Calculation of author based on TLSS 2007. 
The collapse of the Soviet Union led to the breakup of inter-industry links, the closure of many enterprises and a sharp rise in unemployment. The de-industrialisation process led to a fall of employment in industrial production from $21 \%$ in 1991 to $8 \%$ in 2003 (SCSRT, 2006: 88) and expansion of unemployment. Most of the new unemployed found employment in agriculture, the retail trade, services and household production or stopped looking for job completely.

At the same time, the incomes of population also fell. In 1990 per capita income in Tajikistan was $\$ 1,050$ US. However, in two years it dropped by $50 \%$ reaching $\$ 480$ US per capital in 1992, and in 10 years it dropped even further reaching \$150 US in 2001 (SCSRT, 2006: 116). The unemployment caused by structural changes in the domestic economy in transition period as well as expansion in poverty rates serves as the driving forces behind labour migration to external labour markets. ${ }^{3}$

\section{MIGRATION AND MIGRANTS}

International migration has much stronger impact on the level of human capital in Tajikistan. A large percentage of the labour force in Tajikistan has been employed abroad as temporary labour migrants since the trend began in 1994-1995. A comparative look at international figures demonstrates the scale of Tajik involvement in international labour migration. TLSS 1999 showed $1.5 \%$ of households had migrant workers and the figures grew steadily until 2004, when the increase accelerated, reaching 5\% in TLSS 2007. Data from the Ministry of Labour give the total number of labour migrants as 224.000 in 2003, 254.000 in 2005, 727.000 in 2007 and 805.000 in $2008 .{ }^{4}$

Brown, Olimova and Boboev (2008) find that 37.3\% of households had at least one migrant member. The authors find the number of temporary migrants from Tajikistan at about 700000 people, more than 500000 of whom were working in Russia. In autumn 2008 - spring 2009, the number of labour migrants shrank by $25 \%$ or around 120000 people ${ }^{5}$ as Tajikistan experienced a wave of return migration for the first time. These developments were largely due to the world financial crisis and the sharp decline in economic activity in the Russian Federation.

\section{The Profile of Migrants}

To understand how labour migration affects the level of education and human capital, we first have to look at the profile of migrants and in particular at the socialeconomic characteristics of migrants.

3 Although the unemployment rate has decreased over the past 10 years, it still remains quite high at 13\% (Quddusov, 2009).

4 See Olesya Bobovich, “One million working places and no migration” VD 15.10.2009.

5 Data provided by the Migration Service of the Ministry of the Interior of Tajikistan. 
Table 3: Socio-demographic Characteristics of Migrants (\% of the total number of migrant household members in the category)

\begin{tabular}{|l|c|}
\hline & All migrant household members $(\mathrm{N}=1,658)$ \\
\hline Capital & 5.1 \\
Other urban areas & 18.9 \\
Rural areas & 76.0 \\
\hline Male & 93.2 \\
Female & 6.8 \\
\hline 15 years old or younger & 0.4 \\
$16-24$ & 26.5 \\
$25-34$ & 40.2 \\
$35-44$ & 24.5 \\
$45-54$ & 7.8 \\
$55-64$ & 0.5 \\
65 years or older & 0.1 \\
\hline No formal education & 0.4 \\
Primary & 0.9 \\
Secondary & 76.2 \\
Tertiary & 22.3 \\
Post-graduate & 0.2 \\
\hline Unmarried & 39.5 \\
Married & 60.0 \\
\hline
\end{tabular}

Source: Brown, Olimova and Boboev (2008)

The data from Brown, Olimova and Boboev (2008) presented in table 3 indicates that labour migrants from Tajikistan are mostly male (93\% of all migrants), that young men comprise the bulk of these, (66.7\% of all migrants are between $16-34$ years old) and that $76 \%$ come from rural areas. The level of education of labour migrants is higher than the average in Tajikistan; $22.3 \%$ of migrants have higher education and $76.2 \%$ have secondary education.

Table 4 also suggest that unemployment is the main factors driving people to look for higher-paying jobs abroad. More than $60 \%$ of migrants were unemployed in their home country although only $15.6 \%$ were unemployed and were looking for jobs at home. Meanwhile, $10.8 \%$ of the Tajik population was engaged in unpaid work within their household there were three other equally sized groups of students $(6.0 \%)$, the selfemployed $(7.2 \%)$ and those employed in the private sector $(8.4 \%)$. Civil servants formed the smallest group of the employed at $3.6 \%$. 
Table 4: Occupation of Migrants in Tajikistan and Abroad (in \%)

\begin{tabular}{|l|c|c|}
\hline & $\begin{array}{c}\text { In home country } \\
\text { (Base: migrants who } \\
\text { worked in the home } \\
\text { country in 2006: N=83) }\end{array}$ & $\begin{array}{c}\text { Abroad } \\
\text { (Base: all migrants; } \\
\mathrm{N}=1,698)\end{array}$ \\
\hline Self-employed & 7.2 & 19.8 \\
\hline Entrepreneur with hired worker(s) & 0.0 & 4.2 \\
\hline Employed in public sector & 3.6 & 9.3 \\
\hline Employed in private sector & 8.4 & 59.0 \\
\hline Unpaid family work & 10.8 & 1.5 \\
\hline Unemployed (looking for work) & 15.7 & 1.8 \\
\hline Unemployed (not looking for work) & 45.8 & 1.4 \\
\hline Student & 6.0 & 0.9 \\
\hline Retiree with pension & 0.0 & 0.5 \\
\hline Others & 2.4 & 1.5 \\
\hline
\end{tabular}

Source: Brown, Olimova and Boboev (2008)

The figures reflect the long-term migrant status of much of the population as $45.8 \%$ were unemployed in their home country and not looking for a job, representative of the fact that most seasonal workers will return home during the winter but will not seek work.

According to data from Brown, Olimova and Boboev (2008), migrants abroad are prevalently occupied in construction, amounting to $74.1 \%$. Other employment sectors involve the following percentages of migrants: wholesale and retail trade $10.8 \%$, industry $4.8 \%$, agriculture $5.4 \%$, and other sectors (services, education, etc.) $4.8 \%$. Most migrants are employed on a seasonal basis in Russia returning to Tajikistan in the winter.

\section{Destination Countries}

Although, geographically, migration flows from Tajikistan encompass several Commonwealth of Independent States (CIS) countries, labour migration is entirely focused on the Russian Federation ( $97 \%$ migrants). Small numbers of migrants from Tajikistan are employed in other countries such as Kazakhstan $(0.8 \%),{ }^{6}$ PRC $(0.6 \%)$, Uzbekistan $(0.4 \%)$, Afghanistan $(0.2 \%)$, UAE $(0.3 \%)$, and Turkey $(0.2 \%)$. For Tajikistan, we show that for Tajik migrants the most attractive location for employment in the Russian Federation is Moscow metropolitan area: $46.3 \%$ of all migrants having returned from Russia worked

6 Findings of previous studies show changes in migration trends that took place over the last 5 years. In 1999, migrants from Tajikistan mainly headed for the Russian Federation (where 92.86\% of them worked) and for Kazakhstan (7.14\%). By 2002, the number of migrants who worked in Kazakhstan dropped to $1.3 \%$ (Olimova and Bosk, 2003). This reduction is caused by the waning of economic attraction of going to that country, the increased costs of transportation to Kazakhstan and by competition on the part of labour migrants from Uzbekistan. 
there. The main areas of employment are construction, and, to a lesser degree, trade and services sector (Brown, Olimova and Boboev, 2008).

The Siberian Federal District is the second important host territory for Tajik migrants after Moscow and the Moscow Province. Significantly less attractive for migrants are Ural and Privolzhsky Federal District. Some concentration of Tajik migrants can be observed in Ekaterinburg (4.3\%), Tyumen (2.7\%), Nizhnevartovsk (1.2\%), Surgut $(1.4 \%)$ and other Siberian towns. Here migrants work on oil and gas wells, construction, chemical production and industrial enterprises. Attractive are also such large industrial centres as St. Petersburg (6.4\%), Samara (4.4\%) and Rostov upon Don (2.9\%).

\section{Legal Status}

The legal status of migrants is one of the most important factors determining their behaviour, their income, the migration efficiency both for the migrants themselves and the countries of destination and origin. Although labour migration brings huge economic and social benefits to both countries of origin and destination, serious informal and institutional constraints have been created for labour migrants in the CIS. This has resulted in the violation of the legislation regulating the stay and employment in the destination country by many migrants and has lead to the current situation where irregular migration dominates regular migration.

Tajikistan has a visa-free regime with the Russian Federation, therefore Tajik citizens' travel to Russia within a legal framework. However, there are many irregular migrants among the labour migrants from Tajikistan. Sometimes this stems from irregularities concerning registration in the place of residence: $16.5 \%$ of the sample returnees stayed in the places of settlement illegally, that is to say, they have not been registered in OVIR (Department for the Issuance of Visas and Registration), and 8.6\% reported that they registered occasionally. The most frequent reason behind the lack of registration is that every fourth wage worker living abroad said that he saw no reason for registration, since he had to pay bribes to the police in order to be able to stay in a specific area. The same number of informants noted that the registration fee was expensive and they could not afford it. Nearly $70 \%$ of irregular migrants did not leave their workplace, where they lived at the same time.

According to the behavioural survey of migrants the share of workers with an unregulated status reaches $52 \%$. These studies on trafficking in human beings with regard to Tajikistan reveal that more than $70 \%$ of migrants from Tajikistan working in Russia are prone to various forms of trafficking; in other words their freedom of movement is restricted, frequently, they do not have any documents, these documents have often been withdrawn by employers (Olimova and Kurbanova, 2006).

Migrant women register in the place of their residence more frequently than men: $83.3 \%$ compared to $74.7 \%$ of male migrants. However, a significantly higher percentage of women seldom legalise their labour relations $73.3 \%$ compared to $25.6 \%$ of men who work on the basis of a verbal agreement. 
With the enforcement of the new migration legislation in the Russian Federation in 2007, the number of legal migrants, who live and work on the territory of the Russian Federation, has significantly increased. In 2006, the Federal Migration Service (FMS) registered about 30 thousand migrants from Tajikistan, and already in 2007 the number of legal labour migrants in Russia had reached 200 thousand. Nevertheless, in spite of some degree of liberalisation of the migration regime in the Russian Federation, the problem of irregular migration is still pressing.

\section{Return Plans}

According to Brown, Olimova and Boboev (2008), 88\% migrants, who worked abroad in 2006, planned to work abroad in the future, and $83.9 \%$ stated that they would go to work abroad in 2007. Those who were not certain about their future plans constituted $3.2 \% .8 .8 \%$ of the total number of migrants quite clearly did not intend to work abroad in the future.

\section{THE IMPACT OF MIGRATION ON EDUCATION}

When addressing the educational levels of migrants it is necessary to mention that overall the educational level of migrants has fallen over the past 10 years. The question arises if the drop in the educational level of migrants is related to the deterioration of human capital in Tajikistan or rather to the negative effects of labour migration (such as unregulated legal status of migrants). In response to this question we have made the following hypothesis: Collective experiences during migration cause a decrease in the level of migrants' education throughout the migration development process. Due to an unregulated legal status many migrants in destination countries are faced with conditions in which educational background is becoming irrelevant. This collective experience discourages young prospective migrants to improve their educational level.

To accept or reject this hypothesis we need to understand if a higher level of education can provide any competitive advantage to labour migrants in external labour markets. With this purpose we first have to look at the connection between migrants' educational level and their incomes abroad. If higher educational status is highly correlated with higher incomes abroad, then migrant workers may have strong incentive to acquire skills in Tajikistan despite weak incentives for acquisition of skills within the labour market in Tajikistan.

The data collected on distribution of remittances give some indication of the returns on education for migrant workers although there are many other factors involved in the process aside from the ability to earn higher wages on the basis of higher educational status (Brown et al., 2008). Other influential factors range from the strength of family ties to the weakness of the financial system in Tajikistan. However, variation in the distribution of annual remittances on the basis of the educational status of remitting migrants may still offer some degree of insight into the returns on education associated with employment abroad. 
The graph 1 shows that migrants with professional education remit higher sums of money more frequently than labour migrants with any other level of education and there is a general pattern for individuals with a higher terminal level of education to remit higher sums of money more frequently. The average amount of annual remittances sent by labour migrants in the categories of complete basic, secondary and professional education appear to be quite similar at around USD 501-1500, while those from individuals with incomplete basic education are one category lower at less than USD 500. Thus, acquisition of complete basic education guarantees an ability to earn enough to allow remittances on a par with individuals who have completed secondary and professional education.

\section{Graph 1: Distribution of Annual Remittances by Educational Status of Labour Migrants (in USD) ${ }^{7}$}

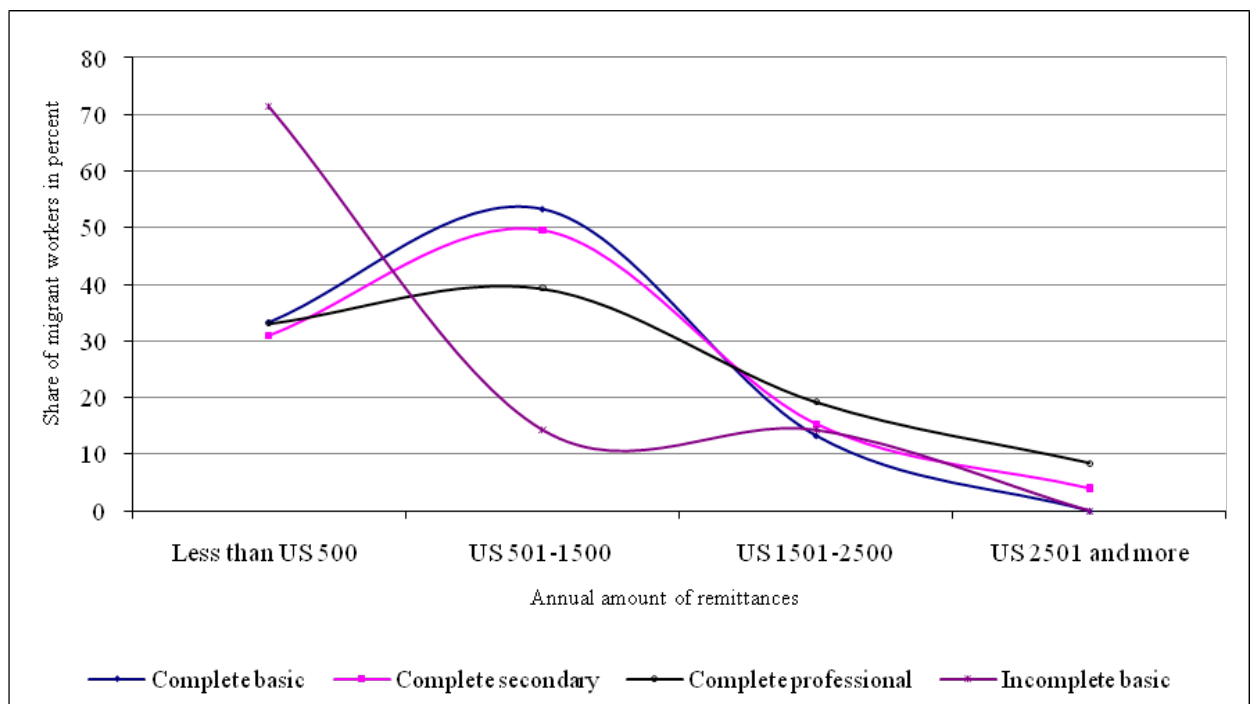

Source: Brown, Olimova and Boboev (2008)

Remittances have a positive impact on poverty alleviation, particularly in rural areas, lowering income inequity and alleviating poverty throughout Tajikistan. Without this income, average poverty incidence would increase by $15 \%$ to $74.5 \%$ of the population, and extreme poverty would climb from $32.2 \%$ to $54.5 \%$ across the country as a whole, and by $25 \%$ in rural areas.

Although labour migration lowers the unemployment rate, workers from Tajikistan are not particularly interested in acquiring professional or technical education at home prior to the move as most of them find work in low skilled sectors such as construc-

7 The category of labour migrants with university education is excluded from the sample due to the very small number of observations (3). 
tion and trade.

Many labour migrants acquire higher skills that improve their productivity and human capital while working abroad. However, very few are given any formal certification of their added capacities so the acquisition of new skills abroad does not easily translate into higher wages.

In 2007, about 700.000 Tajik temporary migrants were working abroad, meaning about $15 \%$ of the economically active population of Tajikistan were labour migrants. More than half a million Tajik people were employed in Russia with significant numbers also in Kazakhstan, the United Arab Emirates and other countries.

Given this scenario, examination of the structure of labour demand and the areas of employment offered in Russia could provide some insight into the incentives for the acquisition of human capital in the form of skills and professional or technical education in Tajikistan.

Brown, Olimova and Boboev (2008) find that $74.1 \%$ of migrants in Russia are employed in construction, $10.8 \%$ in wholesale and trade, $5.4 \%$ in agriculture, $4.8 \%$ in industrial manufacturing and $4.8 \%$ in high skilled services such as education and health care.

The predominant majority of Tajik workers in Russia is employed in industries requiring no or low skills such as construction labour and petty trade, while very few are employed in mid-level skilled areas such as industrial production or higher skilled sectors like health care and education. In this situation, there is little incentive to acquire professional or technical skills beyond the basic literacy level.

However, some labour migrants do increase their human capital by acquiring additional skills and qualifications during employment abroad. The table 5 from Brown, Olimova and Boboev (2008) shows that some labour migrants acquire additional skills they could not learn at home and many workers attempt to acquire professional or technical qualifications abroad by enrolling at local vocational schools or attending short courses, although few succeed in obtaining professional or technical qualifications.

These figures show that $66.1 \%$ of individuals gained proficiency in Russian, which is unsurprising given that the main barrier to increasing the professional level of migrants is the lack of knowledge of Russian. Other obstacles are the absence of specialised programmes for training potential migrants (part-time classes, on-site training, etc.) and mechanisms for funding the education of migrants (educational loans, financial help) in the reception countries. 
Table 5: Additional Qualifications Acquired Abroad

\begin{tabular}{|l|c|c|}
\hline & $\begin{array}{c}\text { Number of } \\
\text { respondents }\end{array}$ & Percent \\
\hline Did not acquire any new qualification & 371 & 58.9 \\
\hline Learned Russian & 416 & 66.1 \\
\hline Learned English & 12 & 1.9 \\
\hline $\begin{array}{l}\text { Acquired new profession and obtained } \\
\text { certificate without examination }\end{array}$ & 11 & 1.7 \\
\hline $\begin{array}{l}\text { Acquired new profession and obtained } \\
\text { certificate after passing an examination }\end{array}$ & 26 & 4.1 \\
\hline Acquired new skills without certificate & 435 & 69.2 \\
\hline Graduated from vocational school abroad & 13 & 2.1 \\
\hline Graduated from university/college abroad & 2 & 0.3 \\
\hline Obtained graduate degree abroad & 4 & 0.6 \\
\hline No response & 9 & 1.4 \\
\hline
\end{tabular}

Source: Brown, Olimova and Boboev (2008) (more than one answer is possible)

\section{Remittances and Education}

The share of expenditures on education and health care in the total structure of household expenditures is small (Table 6). Generally, across the country, the share of expenditures on health care and education in total household expenditures constitutes $3.78 \%$. Data from Brown, Olimova and Boboev (2008) show that the type of residential area and the level of well-being have almost no influence on the share of expenditures on education and health. We can distinguish a slight variation in the share of expenditures on education and health, depending on the level of well-being. Households receiving remittances in the poor quintiles $(1,2$, and 3$)$ spend a little more on education and health than households without remittances do because in Tajikistan these services are not very differentiated in terms of quality and costs. Members of poor and wealthy households consume the same range of medical services in terms of quality. Similarly, the cost of attendance of schools and universities is the same for households of all levels of income.

In general, Tajik households do not make investments in education or health care. Before investing in education, household members need to have a certain degree of confidence about good employment opportunities after education is obtained to cover for the expenditures incurred during their studies. We can attest that members of households in Tajikistan lack this sort of confidence, and consequently, do not heavily invest in education.

The experience of the first decade of labour migration from Tajikistan demonstrates that professional skills of migrants in recipient countries are not in high demand. Since the opportunities for employment even for highly educated and professional indivi- 
duals are scarce, households do not spend resources on education for children.

In addition, the expenditures of education for girls are even less than on boys. Those households, which make investment in education, prefer to provide education mainly for boys, because they hope that educated males will be able to obtain jobs in Tajikistan or elsewhere abroad, thus helping households to procure support when they are old. The investment in education for girls is viewed as bringing no benefit, since girls are expected to leave households at early ages as wives and not to compete in the labour market.

Table 6: Share of Expenditures on Health Care and Education in Total Expenditure (in \%, average for the households in the category)

\begin{tabular}{|l|c|c|c|}
\hline & $\begin{array}{c}\text { All sample } \\
\text { households } \\
(\mathrm{N}=3,300)\end{array}$ & $\begin{array}{c}\text { Receiving } \\
\text { remittances } \\
(\mathrm{N}=1,320)\end{array}$ & $\begin{array}{c}\text { Not receiving } \\
\text { remittances } \\
(\mathrm{N}=1,980)\end{array}$ \\
\hline Total for Tajikistan & 3.8 & 3.7 & 3.9 \\
Dushanbe & 3.4 & 3.1 & 3.5 \\
Other urban areas & 4.3 & 4.0 & 4.5 \\
Rural areas & 3.7 & 3.6 & 3.8 \\
\hline Quintiles based on household income including remittances \\
Quintile 1 & 5.2 & 6.9 & 4.7 \\
Quintile 2 & 4.8 & 4.6 & 4.9 \\
Quintile 3 & 3.9 & 4.1 & 3.8 \\
Quintile 4 & 3.7 & 3.7 & 3.6 \\
Quintile 5 & 2.7 & 2.6 & 2.8 \\
\hline
\end{tabular}

Source: Brown, Olimova and Boboev (2008)

\section{Role of Returning Migrant Workers (Returnees) in Development of Human Capital}

The data obtained from Brown, Olimova and Boboev (2008) show that $9 \%$ of migrants return from abroad to find employment in Tajikistan each year. The basic reasons for returning are age, poor health, family problems and deportation. Working experience and the knowledge acquired abroad offer improved employment prospects for many returnees in Tajikistan. A study of returnees by Olimova (2010) for the International Labour Organization has shown that the experience of employment abroad helped $39.1 \%$ of returnees to find a well paid job in Tajikistan. However, $42.7 \%$ of returnees found this was not the case and $18.2 \%$ found they actually had worse prospects. The same study by the IOM revealed that a total $68.1 \%$ of returnees were employed. Most of the employed returnees preferred to be self employed, running their own business $(21.7 \%)$ or work as independent contract workers (17.3\%). A smaller share of returnees (14.4\%) worked as hired workers in state or publicly owned enterprises and $10.1 \%$ were employed in private 
enterprises. Of the $31.9 \%$ of returnees without jobs, almost $20 \%$ were classed as unemployed; $15.6 \%$ were unemployed and were looking for work and $4.3 \%$ were unemployed and not looking for work.

Our study on returnees (Olimova, 2010: 37) showed that returning migrants actively participate in business development in Tajikistan, but their overall influence on technological development is insignificant.

Returnees play an important role in the modernisation of some enterprises, introducing new technologies and adopting new tools and skills. Meanwhile, work experience from employment abroad is only applied marginally, mostly in small businesses owned and run by the returnees themselves. Hence the greatest impact of adaptation through new techniques, tools and methods introduced by returnees is limited to areas with the highest concentration of small businesses such as services, construction, and manufacturing and the processing and storage of agricultural products. Employers in all these areas prefer to hire returnees and pay them higher salaries.

However, returnees do not have a significant influence on the modernisation of technological process in large state enterprises or in enterprises that undergo extensive and sizeable investment. Also, many enterprises that do not require technological or organisational innovation refuse to hire migrants, meaning that the valuable experience and additional qualification of returnees is not made use of precisely in those areas suffering the most from the lack of qualified workers. The poor health and advanced age of many returnees also form barriers to employment.

If the migrant worker had already been employed before migrating, the departure interrupts his/her career. This problem is aggravated as migrants seldom work in the profession they were trained for, and as a rule, they lose their skills in a certified profession as a consequence. In addition, during their absence the returnees lose the social capital they possessed in Tajikistan and do not accumulate a new one - useful acquaintances, necessary contacts, which would help them to find a decent job in their homeland.

If a migrant formerly worked on a responsible and profitable position, of course after his return he will not be able to occupy this job, as it has been occupied by someone else (interview with migrant Salim, teacher, 45 years old, from Bokhtar,

Tajikistan).

Starting work for a migrant after return from Russia is very difficult. Because, influential acquaintances or big money are required to get a good job or start one's own business (interview with migrant Homidjon, welder, 42 years old, from Isfara,

Tajikistan).

Frequently, the returned migrants have no possibility to use their new experience and skills, they acquired abroad, because of the technological lag in their homeland.

Many migrants fail to find a job after their return, as here the job they were doing abroad does not exist. They are used to working with new technologies. Introducing the technologies, which are being used in Russia, requires much time, money and efforts (interview with migrant Abdunabi, businessman, 30 years old, from Isfara, Tajikistan). 
Nevertheless, even in adverse circumstances the returnees can make use of the skills and of the life experience they have gained in migration in order to organise a profitable activity.

I am a returned migrant, but do not want to get into employment, because my education is not sufficient to find a place with a good salary and it is not profitable to become an ordinary worker - the salary is not enough to sustain the family. Therefore, currently I am working as a taxi driver with my own car (interview with migrant Yokubkhoja, taxi driver, 27 years old, from Isfara, Tajikistan).

Returnees can face problems when their employment abroad is not counted toward their work experience and the period of employment abroad may interrupt their career growth back home. Many migrants will work in different areas of specialisation while they are away and the skills and qualifications they acquired prior to departure may become obsolete. Another common problem for returnees is the lack of opportunity to employ their superior qualifications and experience from employment abroad because of the outdated technology of the respective work sector in Tajikistan.

\section{CONCLUSION}

We find that labour migration has strong effect on the development of human capital of Tajikistan, as $15 \%$ of the population work abroad. Labour migration has both negative and positive effects on education. Migrants with higher education levels tend to send money home more often than migrants with lower levels of education, but, as migrants rarely work in their areas of specialization, the skills and qualifications acquired prior to departure tend to become outdated. However, returnees make a significant contribution to small and medium businesses and agriculture in Tajikistan, bringing new technology, mechanisms, instruments, knowledge and skills. This way, migration serves as a transmitting mechanism for dissemination and adoption of new technology, thereby raising the level of human capital.

Although the education system in Tajikistan prepares individuals poorly for employment abroad and there is no system of professional or technical education for potential migrants, it still provides potential migrants with basic skills such as writing and reading. In return labour migration allows individuals with basic skills to obtain new advanced skills and qualifications. However, as only a very small proportion of individuals have their qualifications certified, the acquisition of new skills abroad does not easily translate into higher wages. In addition, the employment structure for Tajik migrants in Russia encourages labourers to invest in only the minimal level of human capital sufficient for employment in sectors such as construction and trade. The low return on education resulted in a weak demand for educational services and a drop in long-term accumulation of human capital.

The greatest positive effect of migration is the availability of additional resources to spend on education in those families receiving remittances. Children of migrant families have stronger incentives to study foreign languages, have better access to technical equipment and their parents usually have wider horizons, however these households also 
have a higher level of school absenteeism as children are subject to less parental control and are more likely to have to work.

In total the general trends in the post-Soviet transit period resulted in the lower level of education of young people in comparison to their parents, significant drop in the quality of education and a higher inequity in access to education for certain social groups.

\section{References}

ACOSTA Pablo (2006) Labour Supply, School Attendance, and Remittances from International Migration: The Case of El Salvador, World Bank Policy Research, Working Paper No. 3903.

BROWN Richard, OLIMOVA Saodat and BOBOEV Mukhammady (2008) Country Report on Remittances of International Migrants in Tajikistan, in Study on International Migrants' Remittances in Central Asia and South Caucasus, Asian Development Bank, http://www.adb. org/Documents/Reports/Consultant/40038-REG/40038-04-REG-TACR.pdf.

COX EDWARDS Alejandra and URETA Manuelita (2003) International Migration, Remittances and Schooling: Evidence from El Salvador, Journal of Development Economics, 72 (3), pp. 429-461.

DE HAAN Arjan (2005) Migration in the Development Studies Literature: Has it Come out of Marginality?, Paper for UNU-WIDER, Jubilee Conference Future of Development Economics, Department for International Development, United Nations University.

HANSON Gordon and WOODRUFF Christopher (2003) Emigration and Educational Attainment in Mexico, Mimeo, University of California, San Diego.

MCKENZIE David and RAPOPORT Hillel (2006) Can Migration Reduce Educational Attainment? Evidence from Mexico, World Bank Policy Research, Working Paper No. 3952.

OLIMOV Jafar (2007) UNDP Human Development Report: Informal Economy of Tajikistan, Dushanbe, United Nations Development Programme.

OLIMOVA Saodat (2010) Migration and Development in Tajikistan. Emigration, Return and Diaspora (draft), International Labour Organization, Dushanbe.

OLIMOVA Saodat and BOSC Igor (2003) Labour migration from Tajikistan, International Organization for Migration, http://www.iom.int/jahia/webdav/site/myjahiasite/shared/shared/ mainsite/published_docs/studies_and_reports/Tajik_study_oct_03.pdf [16 July 2009].

OLIMOVA Saodat and KURBANOVA Rukhshona (2006) Behavioral Research among Migrant of Tajikistan on HIV and STD, International Organization for Migration, draft, www.ilo.org/ wcmsp5/groups/public/---ed.../wcms_120534.pdf.

QUDDUSOV Jamshed (2009) Labour Market Review in Tajikistan, Working paper.

Republic of Tajikistan (2006) Tajikistan in Figures 2006. Statistical Pocketbook, Dushanbe, State Committee on Statistics of the Republic of Tajikistan.

SCSRT (2006) 15 years of Independence. Statistical Report of Tajikistan 2006, State Statistical Committee of Tajikistan, Dushanbe, 2006.

TLSS (2007) Tajik Living Standards Survey 2007, State Statistical Committee of Tajikistan, Dushanbe.

THIEME Susan (2009) Where to Return to? Rural Urban Interlinkages in Times of Internal and International Migration in Social Research Center, Amercian University Central Asia (AUCA), Policy Briefs on Civil Society. Migration, Islam, and Corruption, Bishkek, AUCA, pp. 108-113.

UNDP (2005) Central Asia Human Development Report, United Nations Development Programme, Bratislava, http://europeandcis.undp.org/poverty/show/300BDC00-F203-1EE9BE944F24EDFC09CE [16 July 2009].

World Bank (2005) Republic of Tajikistan Poverty Assessment Update, World Bank Report, No. 30853-TJ. 